LET: Linguistics, Literature and English Teaching Journal

||Volume |11||Issue||1||Pages||140-157||2021||

|P-ISSN: 20869606; E-ISSN: 25492454|

Available online at: http://jurnal.uin-antasari.ac.id/index.php

\title{
JON M. CHU'S FILM CRAZY RICH ASIANS: \\ THE INTERPLAY OF WESTERN AND EASTERN CULTURES
}

\author{
I Gusti Ngurah Ade Wiraldy \\ 211610005@student.machung.ac.id \\ Daniel Ginting \\ daniel.ginting@machung.ac.id \\ Ma Chung University, Indonesia
}

\begin{abstract}
Article History:
Received: 04 March 2021

Accepted: 05 June 2021

Corresponding Author:

Tel.:

daniel.ginting@machung.ac.id

Keywords:

Social Interactions; Maxims; Chinese; Culture

The film Crazy Rich Asians released in 2018 represents a complexity of social interactions among people with different cultural background. The adaptability to new environments is not always easy; yet, the main character is persistent and capable of maintaining her identity. Being an American born Chinese, Rachel $\mathrm{Wu}$, the main character is depicted as a "banana". --yellow on the outside, white on the inside. Feeling like a curse to feel like an outsider in both the country, the main character was born in or the one her parents come from. The article aims to sketch the profile of Rachel $\mathrm{Wu}$ as a thoughtful, moderate person when dealing with other figures from a society that is exclusively oriented to traditional norms.
\end{abstract}

\section{INTRODUCTION}

People communicate using a language in order to convey their intentions. In so doing, they are able to fulfil their needs. Successful communication takes place if both interlocutors are cooperative (Pickering \& Garrod, 2006; Boyle, Anderson, $\&$ Newsland, 1994; Yule, 1996). This demands that the speakers adhere to the norms of the language. If not, they are likely to mislead and misunderstand others.

I Gusti Ngurah Ade Wiraldy

LET: Linguistics, Literature and Language Teaching Journal Vol. 11 No. 12021 
Language is the mirror of the society (Hymes, 1974). Language as a part of the culture serves a medium for us to see community members' worldview and behavior: a way to think, feel, and act. People are bound by the norms and culture from which they become the members (Housley \& \& Fitzgerald, 2009; Triandis, 1989). Norms are coercive in nature, and humans must obey these rules. For a simple example, American speakers are bound by the rules of English grammar, so are Indonesians bound by Indonesian grammar. If they break the rules, they will never be understood by other parties using the same language. Because of its influential power, a language influences the mental state of the users. People express joy and sadness with their language. In short, a language is reflection of the attitudes, wish, thoughts, and feelings of its users.

The film Crazy Rich Asians released in 2018 becomes the object of this study. This film represents an intricate picture of the interplay of Asian and American cultures. Rachel Wu, physically Chinese, has a western style that is moderate, logical and liberal. Born in America, the character Rachel can be represented as a "banana". --Yellow on the outside, white on the inside. It can feel like a curse to feel like an outsider in both the country she was born in or the one her parents come from.

This film has a lot of dialogues that presents the cultural views of the speakers. The different cultural backgrounds of the characters in the story makes social interactions rigid and full of tension. In fact, avoiding this rigidity during the dialogue process becomes impossible. New York Times on June 23, 2019 reported that the film director, Chu, said that 'Crazy Rich Asians' had a strong social dimension (Ho, 2018). Having been estimated to take up \$30 million for the cost production, this movie has won critics on Rotten Tommatoes. That social aspect of sharing a movie with friends and strangers and family, that's such a strong part of our tradition. Crazy Rich Asians is one of the highest grossing films in various countries where Chinese descent society is dominant such as in Singapore, Taiwan and China. This film provides a big magnet for viewers in these countries to understand the looking glass self or stereotypes of Chinese society in the eyes of people with different cultures.

I Gusti Ngurah Ade Wiraldy 
This research focuses on the theme of politeness as a reflection of the cultural behavior of the movie characters. Politeness is generated as an attempt to adjust the coercive power of cultural norms. Politeness is one of the most popular areas in pragmatics. The modern pragmatic research of politeness started under the influence of the language philosopher Paul Grice's (1975) Cooperative Principle (henceforth $\mathrm{CP})$.

Brown and Levinson's framework has had an authentic impact on the field up to the present day because it provides a universal model of politeness across languages and cultures. Brown and Levinson (1987), and Leech (1983) have generated a significant amount of criticism. The concept of face in Brown and Levinson's work does not coincide with various culture-specific understandings of this notion. Despite criticism, there has been no any alternative framework to expand Levinson's universal view. Instead, research on politeness trend has tended to focus on phenomenon which is co-constructed in a relatively free-flowing way.

The article aims to sketch the profile of Rachel $\mathrm{Wu}$ as a complex liberal, moderate and westernized person when dealing with other figures from a society that is very oriented towards a closed and exclusive culture. To achieve a complete profile, this paper examines the social interactions between characters in films from a pragmatic perspective. Various kinds of utterances that give space to social dimensions such as politeness (Yule, 1996), adherence to principles (Grice, 1975) against maxim are used as analysis tools.

\section{REVIEW OF RELATED LITERATURE}

When people talk to their listeners via a language, they intend to communicate a message to them. Speakers try to get themselves understood by others correctly and avoid misunderstanding. Even if the speakers are able to construct grammatical sentences yet make others confused, the sentences are not meaningful. They do not intended effects. Thus, communicating using a language functionally serves as a basis for all linguistic behaviour.

I Gusti Ngurah Ade Wiraldy 
Pragmatically, the effects resulted from speeches can be measured through scalar of expressions as expressed in the following words: all, most, many, some, few, and none (Levinson 1983). The strongest scalar expression occurs to the left, with strength decreasing as one moves right. When speakers select the word "most", then it also refers to "not all". In reality, people do that: making things "vague". They avoid a rigorous or strong impression. Learning from this example, we can conclude that language users across nations consider contexts involve a social or cultural dimension important aspect to take into consideration. The fact is because they become a part of the community.

Being "cooperative" to the speech context is the necessity to make information exchange among people successful. Cooperative means the messages they convey are mutually accepted in a pragmatically determined context. Grice (1975) calls this concept the cooperative principle (abbreviated $\mathrm{CP}$ ). This principle demands that speakers are demanded to make contribution such as is required, at the stage at which it occurs, by accepted purpose of the talk exchange in which they are engaged. Cooperative Principle (CP) serves to umbrella their four sub-principles: the maxim of quantity, the maxim of quality, the maxim of relation and the maxim of manner.

$\mathrm{CP}$ is indeed an ideal concept. Not few people view CP as "moral code". Yet, it is not always so. In fact, adhering to CP's in day-to-day communication consistently is somewhat impossible. We infer that something else is going on: people flout the maxims for numbers of reasons. These linguistic phenomena are prevalent among societies. For example, the people of Malagasy (Mey, 2004) highly value speaking opaque, convoluted, or non-perspicuous as possible as politeness. These vague language behaviors are a culture-specific way of dealing with sensitive issues (Green, 1989).

Flouting the maxim is intentional in nature. Speakers intend to convey certain effects or indirect addresses to their listeners (Leech \& Thomas, 1988). Note that the pragmatic effects resulted from the flouting practices may not be immediately available. Listeners need to wait for making sense of the meaning of a speech before they are able to give an appropriate response. Misunderstanding often occurs when 
listeners from different cultures have no the same ground about these sort of speeches.

Cultures play an important role in maintaining the existence of society. Cultures, composing of norms, values, rules, are the product of people's social agreement, and they control people's thoughts, emotions, behavior to guarantee order and peace in the society. Politeness, for example, is a representation of a culture that everyone all over the world recognizes. Leech (1983) defines culture as “(s) ome illocutions (e.g. orders) are inherently impolite and others (e.g., offers) are inherently polite. Being inherently polite implies being always polite, without regard for the contextual factors that define what is polite in a given situation. However, the relativism side of politeness needs to be considered according to the context or culture in which the conversation takes place. Illocution about giving "orders" does not become an issue of impoliteness if a general gives orders to his subordinates.

Sensitivity to cross-cultural differences in a society is an important issue for community members to ensure the togetherness and existence of the population.

Multiculturalism refers to a concept that describes various aspects of a society which is ethnically and /or culturally pluralistic (Hannerz, 1999). In a descriptive perspective, multiculturalism refers to cultural diversity of a society in terms of its demographic make-up. Meanwhile, according to a normative perspective, multiculturalism deals with ideologies or policies which aim to promote or institutionalize this diversity. Thus, it can be said that multiculturalism has come to "embody both a description of society and a prescription for managing it" (Malik, 2005, p. 361). Multiculturalists accept the fact that different groups have their own values and lifestyles which should be respected; they support and encourage cultivating minority differences including language, rituals and customs. This is thought to be necessary to ensure the individuals' dignity and self-realization (Citrin et al., 2001).

Multiculturalism is often compared to the concept of assimilation. In assimilation process, minority groups are required to adapt to majority cultural values and practices so that they can successfully function in the society. Minorities 
ought to abandon the beliefs, attitudes and practices which distinguish them from the majority. In assimilation, the native culture is portrayed as the primary one to which all others are to conform. The example for assimilation is a "melting pot" in which all ethnic and national groups become a homogeneous whole with a common culture (Citrin et al., 2001).

Unlike, multiculturalism allows various cultures to mix rather than merge. This model presupposes that multiple ethnic groups can live side by side keeping their distinct, religions, customs and cultures. Second, the key to integration is the respect for values of liberty, democracy, human rights and the rule of law shared by all newcomers. Third, what is also important for the members of minorities is to have basic knowledge of the host society's language, history and institutions. Finally, integration is facilitated by anti-discrimination laws and policies that strongly encourage immigrants to become full members of the society rather than to remain a separate group. Civic integration is thus a two-way exchange - the host society is to provide equal opportunities and resources for immigrants while immigrants are to learn the new language, culture and history of the country as well as act according to its laws.

Based on these literature reviews, we conclude that multicultural competence is not merely about individual being and doing better across differences. Rather, this competency relies heavily on individual awareness and knowledge of institutional structures and organizational processes in society. Pope, Reynold and Muller (2004) state that multicultural competence has a wide range of dominance not only from social identities (White, masculine, Christian, enabled / able, etc) but on other structures of power such as whiteness, religious hegemony, patriarchy and others. structures of power that create disparities in the distribution of resources and life chances. People will have multicultural interpersonal competence if they are able to have awareness, knowledge and skills of the oppressive structure of power.

\section{METHOD}

This study belongs to a descriptive research design as it aims to depict the behavior of the main characters though speeches (Yilmaz, 2013) in the film Crazy 
Rich Asians. Her way of speaking to other characters were analyzed to find out Rachel Wu's personality. The movie scripts became the primary data of the present study. The data analysis focused on the utterances spoken by Rachel $\mathrm{Wu}$ as the main character. In addition, other characters' utterances were also analyzed in order to find the meanings and strengthen the data interpretation. The data analysis of the present study was conducted as follows. The writers managed to familiarize themselves with the data They read data several times and looked for basic observations or patterns. Later, the writers revisited the research objective and identified the questions that could be answered through the collected data. Developing a framework was conducted by turning certain important utterances into codes. The writers identified broad ideas, concepts, behaviors, or phrases and assigns codes to them. For example, the writers put attention to utterances expressing politeness, maxim flouting, implicatures, etc. This coding was helpful for the writers to structure and label the data. Once the data were coded, the writers identified themes that answered research questions.

\section{FINDINGS}

The social interactions in which the main character of the movie, Rachel $\mathrm{Wu}$, engages with other people are complex. She, who grew up in America, has inherited a liberal and logical American thinking style. Her point of view is challenged with other her Chinese fellows whose world life is still ethnically exclusive oriental oriented. In fact, Rachel $\mathrm{Wu}$ is adaptive to different environments. Her abilities to assess the prevailing social norms makes her flexible and fluid to communicate with anyone. The following are findings depicting Rachel's traits in the context of her interactions with others.

\section{Be cooperative}

Rachel $\mathrm{Wu}$ is an effective speaker. This study has found that she manages herself to cooperative in the sense that she does not intend to mislead others. Table 1 shows the results of Rachel Wu's ability to effectively communicate with other people in numbers of social contexts. Nearly all types of maxims (quantity, quality, and relation) have been equally distributed. Rachel is aware that being cooperative 
to the norms of the language is central when to interact with people from other cultures. People see, interpret and evaluate things in different ways. What is considered an appropriate behavior in one culture is frequently inappropriate in another one. Misinterpretations occur primarily when people lack awareness of their own behavioral rules and project them on others. In absence of better knowledge, people tend to assume, instead of finding out what a behavior means to the person involved. In short, Rachel uses this communication strategies in order to maintain good relationships with other people.

Table 1. Types of Maxims

\begin{tabular}{cc}
\hline Types of Maxim & $\%$ \\
\hline Quantity & $25 \%$ \\
Quality & $25 \%$ \\
Manner & $10 \%$ \\
Relation & $40 \%$ \\
\hline Total & $\mathbf{1 0 0 \%}$ \\
\hline
\end{tabular}

The table shows that Rachel predominantly has flouted the maxim of manner even though in general she almost has done all kinds of the flouting. The maxim of manner is flouted when a speaker deliberately fails to observe the maxim by not being brief, using obscure language, not being orderly or using ambiguity. This creates an implicature which makes the participants look for an additional set of meanings. Rachel is trying to obscure the meaning when she speaks to her interlocutors. Rachel intended to be polite that the interlocutors feel good about themselves. Leech mentions that whenever the speaker observes a Maxim of Politeness (s) he flouts a Maxim of the $\mathrm{CP}$, and the hearer may draw inferences accordingly (Leech \& Thomas, 1988).

When she meets older people, she uses long sentences. She has intentionally done that to show that she is interested in chatting with that particular person. A long 
sentence was used by Rachel Chu as a means to give them deference and try to lower herself before them.

\section{ELEANOR}

So, economics. Sounds challenging. (subtly fishing)

Are your parents academics, as well?

\section{RACHEL}

Uh, no. Well, my dad actually died before I was born and, um, my mom didn't even go to college. She actually hardly spoke any English when she immigrated to the United States. But she worked really hard, and she studied, and she earned her real estate license while she was waiting tables to support us. Now, she likes to say that she's Flushing's top real estate broker.

Rachel makes her contribution more informative than is required or can be said. This communication strategy implies exaggeration, giving more information than required. In fact, she does it in purpose, thus she flouts the maxim of quantity. Rachel might be able to give simple answers such as yes or no. However, she deliberately does that because she intends to please her interlocutor, Eleanor. She has mentioned that Eleanor's family background is wonderful. In fact, Eleanor never asks about that topic.

When talking to her peers or her best friends, Rachel flouts the maxim as well. It is to show her open-minded side and her forthrightly personality. For that reason, Rachel makes her sentences short, exaggerating. They appear to be out of the context.

I Gusti Ngurah Ade Wiraldy 


\section{RACHEL}

\section{I can't believe this airport has a butterfly garden and a movie theater. JFK is just salmonella and despair.}

The sentence "JFK is just salmonella and despair" is said by Rachel when she is with her boyfriend. What she said above actually can be considered as flouting the maxim of quality. This is because Rachel says something that is not based on facts and leads to lies. It can be considered as exaggerating sentence as well. So, we can see that she deliberately shows her forthrightly personality in front of her boyfriend through her opinion about Changi Airport.

In most Rachel's conversations, she does covey her messages indirectly by not being direct with the answer (Thomas, 1995). She is intentionally ambiguous. Flowerdew (2013) provides the example "Go to work on an egg" which means either that 'an egg should be eaten before work' or that the hearer 'should start eating an egg'. This works since it is possible in both the metaphorical and in the literal sense of the sentence (Flowerdew, 2013). According to relevance theory, all maxims can be subsumed under the maxim of relation. The only message that is needed in a conversation is that the information is relevant enough for the recipient to understand, which makes the other maxims redundant (Cruse, 2000). The speaker who is conveying information is of the belief that the utterance holds enough relevance for the receiver to understand the information that is being conveyed.

\section{Being Polite}

Rachel Chu has social awareness of other people's face-wants. She is very attentive to her utterances. She manages her thoughts and ideas so that what she says through language does not threaten other people's good image. 
Table 2. Politeness Strategies used by Rachel

\begin{tabular}{ccc}
\hline $\begin{array}{c}\text { Types of Politeness } \\
\text { Strategies }\end{array}$ & Freq. & $\%$ \\
\hline $\begin{array}{c}\text { Positive Politeness } \\
\text { Strategy }\end{array}$ & 30 & $54,5 \%$ \\
$\begin{array}{c}\text { Negative Politeness } \\
\text { Strategy }\end{array}$ & 10 & $18,2 \%$ \\
Bald on Record Strategy & 8 & $14,5 \%$ \\
Off Record Strategy & 7 & $12,8 \%$ \\
\hline Total & $\mathbf{5 5}$ & $\mathbf{1 0 0 \%}$ \\
\hline
\end{tabular}

There is a very minimal tendency where Rachel Chu applied bald on record or off record strategies in her sentence. Bald on record in politeness strategy is considered too rough in communicating with others. This strategy can easily hurt the listener's heart. Whereas in the off record strategy, this strategy is considered to be very ineffective because we need to make our listeners understand our intentions without us saying our wants directly. Rachel Chu was found very rarely using both of these strategies.

Then, what strategies does she often use to communicate with others? Positive Politeness Strategy. The use of positive politeness strategy shows that Rachel has a desire to build friendship and claim common ground with her interlocutors. Rachel believes by carefully choosing her words that tend to give a compliment and pay attention to what the other person wants, Rachel's interlocutors will definitely be kind to her and also expected to grant her face wants too like what Rachel has done to them. Moreover, if Rachel has a good impression from them, her relationship with those people can be potentially maintained good in the future as well. For example: 


\section{RACHEL}

Wow! Oh, my gosh! Your house is amazing, Mrs. Goh.

\section{NEENAH}

Li gaou kong wei ah. [You're such a sweet talker.]

Rachel who has just met Neenah for the first time opens the conversation by praising her beautiful home. The way Rachel praises is classified as positive politeness strategy because she simply exaggerate her expressions in order to please other people. In so doing, Rachel not only selects words but also pays attention to her intonation. This communication strategy makes people think that Rachel likes Neenah's house. By using this strategy, Rachel hopes that Neenah will have a good impression on Rachel, and they become good friends in the future. Rachel has flouted the maxims since she is often polite. She has used flouts when she intends to show disagreement indirectly with someone. In fact, it does not happen very often.

Rachel does politeness to indicate that she takes others' feelings of how they should be treated into account. From the story, Rachel is aware of being polite before other people through her assessments of interactional behavior. In fact that, it helps people to build up and maintain interpersonal relationships. The operation of politeness involves people's social sensitivity: as they behave in what they perceive as polite in a given situation, they attempt to maintain shared values with others. These acts trigger positive emotions, keeping other faces safe. Rachel's treatment to others reflects her perceived moral order of an interactional context/event. She does that because she knows 'how things should be' in a given situation. In short, we can conclude that Rachel is aware of social context where norms or conducts have to be upheld. Her examination of politeness reveals information about the broader ingroup, social, and cultural values that underlie the evaluative interactional behavior of individuals.

I Gusti Ngurah Ade Wiraldy 


\section{Living in harmony}

That Rachel is very aware of her own word choice is because she has strong desire to build good common relationships with people around her. As a visitor from another country, Rachel must be very strange to the new culture that she found in Singapore. She does not know whether Singaporeans is free or open-minded like Americans. The best way to get along easily with Singaporean is by being friendly and polite.

In Crazy Rich Asians movie, that Rachel always distinguishes her choice of words when communicating with people she just met and people she has known for a long time. With a new person that she has just met or with an elderly people, Rachel tends to always use polite words, lots of compliment, often lifting the person's degree and seemed to like granting that person's face wants through her words. With that way, Rachel is considered as a kind, friendly, and warm person. Rachel hopes, by elevating the person's degree, that person have a good first impression on Rachel. Thus, their relationship will last long in the future.

\section{RACHEL}

Grandma, thank you for inviting me to your home. Nick always talks about you. He says no one in the world makes better dumplings.

\section{AH MA}

It's nothing. I can show you how to make them, too.

\section{RACHEL}

I would be honored.

Rachel chooses a polite language when communicating with people she had just met, and especially if the person was much older than her like in this example. She gives praise/compliment to that person, and also elevates that person's degree in order to please that person's face wants.

I Gusti Ngurah Ade Wiraldy 
Meanwhile, if she communicates with her peers, Rachel wants to maintain their relationship in a good way through friendly and outgoing communication. She prefers to have good relationship with her friends. She is eager to maintain long lasting relationship in the future. If she uses language that is too rigid, praises a lot, or exaggerates as like she does with people she just met, it is certain that Rachel's friends will feel uncomfortable communicating with Rachel.

\section{PEIK LIN}

What about the Ah Ma? Does she hate your face, too?

RACHEL

Okay, nobody said they hated my face. And Ah Ma, she liked my face. She said I had a lucky nose.

When Rachel talks to her best friend, Peik Lin, she seems to able to free from being cultural rigidity. She talks whatever she wants to say. She seems to not care much on choice of words. She tends to say what is in her brain clearly without thinking about whether her words can hurt her listener or not. Her language is casual: no small talk nor praise for Peik Lin. Yet, Rachel is fully aware of what she does to her friend.

\section{DISCUSSIONS}

Rachel is the representation of a person capable of adjusting and adapting to different social environments. She was raised by her Chinese mother who taught her to be attentive to other people's conditions. Rachel Chu is a child of Chinese immigrants who have moved to America. Her former Asian cultural plays an important role in shaping her worldview and maintaining social relationship with others. Rachel Chu's mother is still a native Chinese who was born and raised in a thick Chinese culture. Having been raised in America, she still adheres to her Chinese cultural background through her mother. Raised in America, she also inherits westerner's point of view which is logic, moderate and somewhat liberal to 
some extent. Rachel has developed in a free and open environment. Americans are widely known often communicate in a blunt way/straightforward (Callahan, 2007; Kim, 2008). Rachel is more willing to use her American side when communicating with her close friends because the possibility that she threatens their friends' faces will be smaller rather than use it with new person that she just met.

Former cultural background has strongly influenced on the way people behave in many ways (Matsumoto, Frank, \& Hwang, 2012). In Rachel's case, she is taught to adhere to Chinese culture. In Chinese culture, politeness is described in very specific ways. In Chinese culture, Chinese people recognize the term gei mianzi (给 面子). This term can be defined as an effort of one person to take care of the other's self-appreciation even at the cost of sacrificing his/her own interest at the moment. The Chinese people assume, "if you give him face, and he will give you the whole world.” (In Chinese: 妳給他面子, 他就給妳全世界) (Kadar, 2011)

Living in harmony is one of the big issues in Asian culture (Kim, 2011). Being aware of other people's faces is the necessity and it becomes common practice in Asian's culture. People are taught to put knowledge into practice in daily conversation. Asian are taught to maintain good relationship with other people although they have to sacrifice their own interests. Not few Asian tend to agree with the majority despite their own ideas. Living in harmony means that establishing friendship with others is important. Asians are taught to be attentive to other people's face. In Rachel's case, she manages to grant her interlocutors' face. In so doing, the relation may last long.

Rachel has passion on a multiculturalism tendency. Multiculturalism refers to situations in which people who hold 'different' habits, customs, traditions, languages and/or religions live alongside each other in the same social space, willing to maintain relevant aspects of their own difference and to have it publicly recognized (Colombo, 2014). It can be said that in multiculturalism, the people 
always deal with the acceptance of the presence of other cultures without diluting or losing their original cultural identity.

\section{CONCLUSIONS}

Rachel Chu regards establishing a good social relationship with the other characters is important. She is very selective in using maxim flouting and politeness strategies. Rachel does all kinds of maxim flouting in an almost equal way but based on 2 different occasions. If she meets a new person he knows, she uses maxim flouting to show her interest in chatting with that particular person. With her close friends, she maintains casual personality.

Rachel uses all kinds of politeness strategies in her conversations with her interlocutors. However, she showed a tendency to use positive politeness strategies more often than other politeness strategies. This shows that she wants to build friendship with her interlocutors and also claim common ground against them. In common relationship tendencies, Rachel always distinguishes her choice of words when communicating with people she just met and people she has known for a long time.

Rachel always uses polite words, lots of compliment, and often lifting the person's degree when meeting people at the first time. Rachel manages to build a good image as a person who is kind, friendly, and warm. When conversing with her peers, Rachel is also concerned with maintaining their relationship. She does that through friendly and outgoing communication styles.

Rachel adores multiculturalism point of view, viewing different people with all respect. She has Chinese Culture as her original culture and American Culture as her new culture inside herself. When communicating with her close friends, Rachel is more willing to use her American side. However, when Rachel talks with a new person, she is more willing to use her Chinese side to show a good image in front of her interlocutors. The implication of this research is that to build good social relationships with other people requires a good understanding of other people's cultures. We must be willing to be open minded and tolerant of those differences. In 
addition, people must learn to respect and respect others. Maintaining the dignity of others by maintaining polite language is another value that people need to pay attention to in order to maintain a harmonious life in society.

The conclusions of this study must be understood with caution. This study has limitations in analyzing human behavior in social interactions through the perspective of Pragmatics. To understand further about such phenomena, it is certainly not enough to rely on one theoretical approach alone. Therefore, the author suggests other researchers to sharpen the analysis of this film with multiple approaches such as sociology, multiculturalism and so on. As a result, the social phenomenon in the film will be more completely presented.

\section{REFERENCES}

Boyle, E. A., Anderson, A. H., \& Newsland, A. (1994). The effects of visibility on dialogue and performance in a cooperative problem solving task. Language and Speech., 37(1), 1-20.

Brown, P., \& Levinson, S. (1987). Politeness: Some universals in language usage. Cambridge, U.K.: Cambridge University Press.

Callahan, D. (2007). The cheating culture: Why more Americans are doing wrong to get ahead. NY: Houghton Mifflin Harcourt.

Citrin, J., Sears, D. O., Muste, C., \& Wong, C. (2001). Multiculturalism in American public opinion. British Journal of Political Science, 31, 247-275

Colombo, E. (2014) 'Multiculturalisms.' Sociopedia, 1-17. doi:

$10.1177 / 2056846014101$.

Cruse, D., A. (2000). Meaning in language: An introduction to semantics and pragmatics. Oxford: Oxford University Press.

Flowerdew, J. (2012). Discourse in English language education. New York: Routledge.

Green, G., M (1989). Pragmatics and natural language understanding. Hillsdale, NJ: Lawrence Erlbaum Associates

Grice, P. (1975) 'Logic and Conversation', 41-58. doi: 10.1093/alcalc/agw081.

Hannerz, U. (1999). Reflections on varieties of culturespeak. European Journal of Cultural Studies, 2, 393-407.

I Gusti Ngurah Ade Wiraldy

LET: Linguistics, Literature and Language Teaching Journal Vol. 11 No. 12021 
Ho, K., K (2018). Crazy rich Asians is going to change Hollywood. It's about time. Time online magazine. https://time.com/longform/crazy-richasians/

Housley, W. \&. (2009). Membership categorization, culture and norms in action. Discourse \& Society, 20(3), 345-362.

Hymes, D. (1974). Foundations in Sociolinguistics: An ethnographic approach. Philadelphia: University of Pennsylvania Press.

Kadar, D. Z. (2011) 'Politeness in China.' Politeness in East Asia, 125-146. doi: 10.1017/CBO9780511977886.008.

Kim, H. S. (2008). Culture and social support. American Psychologist, 63(6), 518526.

Kim. K., H. (2011). Exploring the Interactions between Asian culture (Confucianism) and creativity. Creative behavior, 41(1), 28-53.

Leech, G. (1983). Principles of pragmatics. London: Longman.

Leech, G., N. \& Thomas, J. (1988). Pragmatics: the state of the art. Lancaster University: Lancaster Papers in Linguistics

Levinson, S., C. (1983). Pragmatics. Cambridge: Cambridge University Press.

Matsumoto, D., Frank, M. G., \& Hwang. H., S. (2012). Non verbal communication. New York, NY: Sage Publication.

Malik, K. (2005). Culture, race and social policy. Patterns of Prejudice, 39(4), 361-378.

Mey, J.,L. (2004). Pragmatics. An introduction. Oxford: Blackwell Publishing

Pickering, M., \& Garrod, S. (2006). Alignment as the basis for successful communication. Research on Language and Computation, 4(1), 203-228.

Pope, R., Reynolds, A., \& Mueller, J.A (2004). Multicultural competence in student affairs. New Jersey: Jossey-Bass Wiley

Thomas, J. (1995). Meaning in interaction: An introduction to pragmatics. London: Longman

Triandis, H. C. (1989). The self and social behavior in differing cultural context. Psychological review, 96(3), 506-520.

Yilmaz, K. (2013). Comparison of quantitative and qualitative research traditions: Epistemological, theoretical, and methodological differences. European Journal of Education, 48(2), 311-325.

Yule, G. (1996). Pragmatics. New York: Oxford University Press.

I Gusti Ngurah Ade Wiraldy

LET: Linguistics, Literature and Language Teaching Journal Vol. 11 No. 12021 